\section{A FELELŐSSÉGBIZTOSÍTÁSOK SZEREPE, JELENE ÉS JÖVŐJE MAGYARORSZÁGON}

Pandurics Anett, Markó Olga ${ }^{\star}$

Kulcsszavak: felelősségbiztosítás, vezetői felelősségbiztosítás, kártérítési jog, kockázatmenedzsment, piaci struktúra, gazdasági stabilitás

JEL: D4, G22, G32, K13

DOI: $10.18530 /$ BK.2015.3.78

http://dx.doi.org/1018530/BK.2015.3.78

\section{ÖSSZEFOGLALÓ}

A felelősségbiztosítások legfontosabb jellemzője az a hárompólusú, bonyolult jogviszony, amely annak eredményeként áll elő, hogy a felelősségbiztosítást nyújtó biztosító a biztosított által másnak okozott károk megtérítésére vállal kötelezettséget. Miközben a felelősségbiztosítások fontos szerepet töltenek be a vállalatok felelősségi típusú kockázatainak kezelésében, Magyarországon a felelősségbiztosítási penetráció nemzetközi összehasonlításban alacsony. A cikk célja az, hogy bemutassa a felelősségbiztosítások fogalmát, sajátosságait, szerepét és jelentőségét, valamint a magyar felelősségbiztosítási piac jelenét és a jövőben várható tendenciákat, mindezt elsősorban a vállalati felelösségbiztosításokra koncentrálva.

A kockázat, a bizonytalanság életünk elkerülhetetlen része, ugyanakkor a kockázatokat tudatosan kezelhetjük különböző technikákkal. A váratlan eseményekre való felkészülés, a kockázatok kezelésének egyik eszköze a biztosítás. Megfelelő kockázatkezelési technika nélkül a ritkán előforduló nagyobb károk tönkretehetik az érintett céget, kompenzáció nélkül hagyhatják a károsultakat, és negatív hatást gyakorolnak a gazdaságra (a volatilitás növelésével, valamint a helyreállítás terheivel). A biztosításoknak és köztük a felelősségbiztosításoknak a kockázatok porlasztása révén alapvető stabilizáló szerepük van.

\section{A felelősségbiztosítás fogalma és sajátosságai}

A magyar polgári törvénykönyv szerint „a felelősségbiztosítási szerződés alapján a biztosított követelheti, hogy a biztosító a szerződésben megállapított módon és mértékben mentesítse őt olyan kár megtérítése, illetve sérelemdíj megfizetése alól amelyre jogszabály értelmében köteles” (Ptk, 2013; 6:470§). A felelősségbiztosítások legfontosabb jellemzője az a hárompólusú, bonyolult jogviszony (biztosító - biztosított károkozó - károsult), amely annak eredményeként áll elő, hogy a felelősségbiztosítást nyújtó biztosító a biztosított által másnak okozott kár megtérítésére vállal kötelezettséget. Szerződéses kapcsolat csak a biztosító és a károkozó biztosított között van. A kárt végső soron megtérítő biztosító ugyanakkor nem áll szerződéses viszonyban a károsulttal, aki főszabályként közvetlenül nem is fordulhat kárigényével a biztosítóhoz, a kárrendezési folyamat során mégis szükségszerűen jogi kapcsolatba kerül vele.

A felelősségbiztosítási kockázatokat úgy lehet meghatározni, mint a vállalkozások (vagy magánszemélyek) azon költsége, amely a tevékenysége során másoknak okozott károk jogszabályon alapuló megtérítési kötelezettségéből adódik. Ez a kockázat a céget érintő kulcsfontosságú kockázatok egyikének tekinthető, és az adott társaság tevékenységének jellegétől, méretétől és a vonatkozó jogszabályi környezettől függően a kockázat típusa sokféle lehet. A biztosítatlanság esetén tipikus kockázatkezelési technikákon kívül (mint a kockázat elkerülése, veszteségkezelés, kockázatmegtartás) a felelősségbiztosítás a piaci szereplők felelősségi kárait fedező hatékony kooperatív kockázatkezelési módszer. A felelősségbiztosítás olyan speciális szerkezetű termék, ahol a biztosítótársaság a biztosított (pontosabban a cég vagy a cégvezető) által okozott veszteségeket, károkat fedezi. Ebben az esetben a biztosítótársaság azokat az adott cég számára veszteségként jelentkező kártérítéseket fedezi, amelyekért a biztosított jogi értelemben felel (Trieschmann et al., 2005).

A felelősségbiztosítást sajátosságai megkülönböztetik más nem-életbiztosítási termékektől, különösen a vállalati vagyonbiztosításoktól. A legfontosabb objektív különbség (amint azt az 1. táblázat is mutatja) az, hogy a károkozással kapcsolatban sokkal nagyobb és több a bizonytalanság. Épp ez teszi komplexebbé a felelősségbiztosítás világát. ${ }^{3}$

A felelösségi károk sokkal nehezebben becsülhetők, mint a vagyonbiztosítások, mert a kártérítési felelősséget kiváltó események sokkal nehezebben láthatók elöre. Továbbá nem segíti a kalkulációt egy olyan egyértelműen meghatározható összeg, mint a biztosított vagyontárgyak értéke, ami a maximális biztosítási összeg rögzítéséhez nyújt segítséget. Fontos különbség, amely megkülönbözteti a felelősségbiztosításokat más ágazoktól, az is, hogy a kár maga nem független a biztosítottól, hiszen definíciójából adódóan az általa okozott károkra vonatkozik a fedezet. Ebben az esetben a biztosító számára fogódzót a biztosított személye, illetve az általa végzett tevékenység ad, nem jelent segítséget a biztosítási összeg (pl. casco esetében a gépkocsi értéke nyújt támpontot). Az információs aszimmetria és az erkölcsi kockázat (moral hazard) kezelése, a megfelelő ösztönzési rendszer kialakítása a biztosító feladata.

Másrészt a károk nagysága (és a kárigény-érvényesítési hajlandóság maga is) sokkal nagyobb mértékben függ az adott jogi-politikai környezettől. Nagy-Micski (2012) hangsúlyozza, hogy a kártérítéssel kapcsolatos attitűd időben változik, azt befolyásolja a fogyasztói tudatosság változása, a bíróság kártérítési pergyakolata, az információk publicitása és 


\begin{tabular}{|c|c|c|}
\hline & $\begin{array}{l}\text { Vállalati } \\
\text { felelösségbiztosítás }\end{array}$ & $\begin{array}{c}\text { Vállalati } \\
\text { vagyonbiztosítás }\end{array}$ \\
\hline $\begin{array}{l}\text { Kártérítési kötelezettséget kiváltó } \\
\text { események (milyen esetben fizet a } \\
\text { biztosító) }\end{array}$ & $\begin{array}{l}\text { A biztosított minden olyan } \\
\text { jogellenes károkozó magatartása } \\
\text { kiváltó esemény, amely nincs } \\
\text { kizárva a szerzoodésben (amire a } \\
\text { biztosítási fedezet vonatkozik). }\end{array}$ & $\begin{array}{l}\text { A szerző́désben rögzített } \\
\text { vagyontárgy megnevezett (all } \\
\text { risk fedezetnél a nem kizárt') } \\
\text { veszélynem általi károsodása. }\end{array}$ \\
\hline $\begin{array}{l}\text { Biztosított kockázatok } \\
\text { (mit fizet a biztosító) }\end{array}$ & $\begin{array}{l}\text { A biztosított károkozása } \\
\text { miatt keletkezett károkat téríti. } \\
\text { Harmadik személyek felelösség- } \\
\text { biztositási dologi és személyi sé- } \\
\text { rüléses kárigényeire vonatkozik, } \\
\text { a biztositás hatókoore gyakran } \\
\text { bizonytalan. } \\
\text { Ok: emberi tevékenység }\end{array}$ & $\begin{array}{l}\text { A biztosított vagyontárgyban } \\
\text { keletkezett, csak vagyoni tipusú } \\
\text { károk megtéritese. } \\
\text { Ok: természeti ok és'vagy emberi } \\
\text { tevékenység }\end{array}$ \\
\hline $\begin{array}{c}\text { A kár nagysága } \\
\text { (mennyit fizet a biztosító) }\end{array}$ & $\begin{array}{c}\text { A kártérités felső határai a } \\
\text { biztositó számára a biztosittási } \\
\text { szerződési limitek (de maximum } \\
\text { a tényleges kár); a jogi képvisele-e } \\
\text { ti költségeket akár a limiten felül } \\
\text { is állnia kell a biztositónak². }\end{array}$ & $\begin{array}{l}\text { A kártérítést a biztosítási szer- } \\
\text { zódési limitek és a biztosititott va- } \\
\text { gyontárgyak értéke korlátozzák. } \\
\text { A kárterítés a biztositási összeg, } \\
\text { de maximum a vagyontárgyak- } \\
\text { ban bekövetkezett kár érteke. }\end{array}$ \\
\hline $\begin{array}{l}\text { A díjfizetés és a kárrendezés közti idó } \\
\text { (mikor fizet a biztosító) }\end{array}$ & $\begin{array}{l}\text { Hosszabb átfutási idő. A } \\
\text { kárról történő tudomásszerzés } \\
\text { késedelmes lehet, és a kártérítés } \\
\text { kifizetéséhez hosszabb idő } \\
\text { szüksséges, a felelösség egyér- } \\
\text { telmü megállapítása is több időt } \\
\text { igényelhet. }\end{array}$ & $\begin{array}{l}\text { Alltalában nincs/kevés késedelem } \\
\text { és relatív gyors kárrendezés. }\end{array}$ \\
\hline
\end{tabular}

1. táblázat: A felelösség- és vagyonbiztositások legfontosabb különbségei

(Forrás: Swiss Re (2014), 2. oldal alapján, a szerzök által módositva)

akár az ügyvédek aktivitása is. Ezek a tényezők lényegesen befolyásolják az ügyfelek kárigény-érvényesítési aktivitását.

Harmadrészt a kárrendezési folyamat átfutási ideje jellemzően hosszabb (akár éveket, évtizedeket vehet igénybe egy kár lezárása). Ezen belül már a kárigény felmerülése, a kárbejelentés maga is - akár objektív okok miatt - jelentős késéssel (akár a szerződés megszűnését követően is) történhet. Amennyiben nagyobb összegü és bonyolultabb kárigényről van szó, akkor nagyobb a valószínűsége, hogy a rendezéshez komoly jogi szakértőkkel támogatott hosszabb jogi eljárás szükséges, hiszen a felelösség megállapítása és a kárösszeg meghatározása (különösen személyi sérültes károk és továbbgyűrűző károk esetén) sok esetben valóban nagyon komplex kérdés. A felelősségbiztosításokat klasszikus hosszú lefutású (long-tail) módozatnak nevezi a szakirodalom, ami olyan káreloszlást jelez, amelyben sok kis kár jelentkezik, ugyanakkor van néhány nagyon nagy kár is, ezért hosszú a farka az eloszlásnak. A felelősségbiztosításoknál nagyobb a bekövetkezett, de még be nem jelentett károk aránya is, mert objektíven is hosszabb idő telhet el a károkozás és annak bejelentése között (pl. gyakran később derül ki, hogy jóval korábban felelősségi káresemény történt egy-egy orvosi mühiba vagy ügyvédi tévedés miatt). Az ilyen módozatok esetében nagy valószínűséggel magasabb IBNR-tartalékképzés ${ }^{6}$ szükséges.

A szakirodalom szerint a felelősségbiztosítások (illetve általában a biztosítások) iránti kereslet közgazdasági alapját az ügyfelek kockázatkerülő (risk averse) magatartása adja, ami azt jelenti, hogy az ügyfelek határhaszna csökkenö, vagyis minden plusz forint (a pénzügyi pozíció javulása) egyre kevesebbet ér számukra (a plusz forintok határhaszna csökkenő). Fordítva megközelítve, egy lehetséges nagy veszteség (nagy egyszeri csökkenés egy káresemény kapcsán a pénzügyi pozícióban) fájdalmasabban érinti őket, mint a fair biztosítási díj folyamatos negatív, de kisebb mértékű cash-flow hatása (ami sok kisebb veszteségként is felfogható). Egy racionális kockázatkerülő ügyfél a nagy veszteséget el kívánja kerülni, és a biztosítási védelem mellett dönt.

\section{A felelösségbiztosítások története és szerepe}

A felelösségbiztosítás modern és fiatal biztosítási forma, amelynek gyökerei a XIX. századi iparosodáshoz köthetők. Az első felelősségbiztosítási kötvényt Angliában bocsátották ki 1881-ben, és 1889-ig ez a biztosítási forma Európában és Amerikában együttesen sem érte el azt a volument, hogy komolyabb figyelmet érdemeljen. Ezt követően azonban folyamatos fejlődésnek indult, elsősorban a munkaadók gondatlansággal kapcsolatos jogi felelőssége miatt keletkező kötelezettségek fedezésének igénye miatt. 1904-ben a becslések szerint 14.700.000 \$-t fordítottak az Egyesült Államokban felelösségbiztosításokra. ${ }^{7}$ Az első vezetői felelösségbiztosítási kötvényt szintén Londonban, 1930-ban bocsátotta ki a Lloyd's, és ez a típus az 1980-as években kezdett jelentős mértékben terjedni. ${ }^{8}$

A felelősségbiztosítások szerepével kapcsolatban kritikus, illetve ellenmondásos hangok is megjelentek a kezdetektől fogva. Ezek elsősorban azt a lehetséges negatív mellékhatást fogalmazták meg kritikaként, amely szerint a felelősségbiztosítás csökkentheti a megelőzésre fordított figyelmet, növelheti a gondatlan károkozás kockázatát, csökkentve az elrettentő erőt, amelyet a jogrendszer a kártérítéssel kapcsolatos felelősség révén el kíván érni (ex ante moral hazard). A felelősségbiztosítások támogatói ugyanakkor a kezdetektől hangsúlyozták ezen biztosítások ún. kompenzációs szerepét, amely révén a károsultak megfelelő kártérítéshez juthatnak (abban az esetben is, ha ez a kárért felelős anyagi lehetőségeit meghaladja). Emellett a biztosítási intézményrendszer számos eszközzel rendelkezik az említett kritikai hangok által felvetett morális kockázat csökkentésére (ilyen például az önrész és a limitek alkalmazása, a szerződéses kizárások vagy épp az alapos kockázatértékelés és a kockázatalapú árképzés). Az utóbbi időben egyre több figyelmet kap a felelősségbiztosításokkal kapcsolatos lehetséges ex post morális kockázat (ex post moral hazard) is, amely szerint az áldozatok/károsultak nagyobb arányban és mértékben jelentenek kárigényt akkor, ha a károkozó rendelkezik felelősségbiztosítással. Ennek a lehetőségnek a jóléti hatása egyelőre nem egyértelmű. A szakirodalom arra a következtetésre jut ${ }^{9}$, hogy 
a felelösségbiztosításoknak összességében pozitív, társadalmi jólétet növelő hatásuk van, amely a következőkben jelenik meg ${ }^{10}$ :

- csökkenti a magánszemélyek és vállalkozások kockázatait, stabilizáló szerepet tölt be, hiszen anyagi védelmet, pénzügyi biztonságot jelent a károsultnak (adott esetben a károkozó teljes vagyonát meghaladó mértékben), és egyben a károkozót is védi (felelősségbiztosítás hiányában ugyanis a károkozó saját vagyonával felel),

- stabilizáló hatása révén pozitív hatást gyakorol a gazdasági növekedésre (simítja a jövedelmeket és a fogyasztást, ösztönözheti a beruházásokat, csökkentheti a vállalatok tőkeszükségletét),

- a veszélyközösség létrehozásával a felelősségbiztosítás olcsó kooperatív kockázatkezelési módszer, amely hatékony abban az esetben, ha a kockázatközösség tagjainak felelősségi kárai nem túl erősen korrelálnak egymással ${ }^{11}$,

- az intézményrendszer (a biztosítón keresztül) járadékfizetésre is alkalmas, ezzel hosszú távú biztonságot nyújt a károsultak számára személyi sérülés esetén,

- a kárrendezési szolgáltatás révén csökkenti a károkozó és a károsult között felmerülő természetes konfliktusokat, feszültségeket, ezzel a felelősségbiztosítás egyfajta mediációs szerepet tölt(het) be ${ }^{12}$,

- amennyiben a biztosított ellen indított kártérítési perben a biztosító részt vehet, szakértelmével és tapasztalatával támogathatja a biztosítottat a peres eljárásban,

- kárrendezési apparátus igénybevételével lehetővé válik a tömegkárok gyors rendezése, a professzionális kárrendezési szolgáltatás biztosítása katasztrófák idején értéket jelent (erre specializálódva hatékonyabban képes kárt rendezni, mint más szereplők).

A felelösségbiztosítási szakma tandemben, kéz a kézben fejlődött a felelősségi károkra vonatkozó jogrendszerrel, s amint azt Abraham (2008) is hangsúlyozza, ebben az esetben kölcsönös egymásra hatásról van szó, ami kiemelt figyelmet érdemel. Mivel a biztosítótársaságok a károkozó oldalán aktív szereplői a kártérítési folyamatnak, magatartásuk mind a jogi környezetet, mind a biztosítások iránti keresletet befolyásolja. Józan ésszel is könnyen belátható, hogy a biztosítók hatással vannak arra, hogy például milyen káresemény kapcsán kerül sor peren kívül megállapodásra a felek között, és ez milyen tartalommal születik meg. A biztosítók aktív részvételükkel a bírósági tárgyalások végeredményét is befolyásolhatják, önmagában a biztosítási fedezet léte befolyásolhatja a kárigény-érvényesítési hajlandóságot és a kártérítési per összegszerűségét is. A kártérítési megállapodás és perek pedig alakítják a vállalatok felelősséggel kapcsolatos percepcióit, és visszahatnak a felelősségbiztosítás iránti keresletükre.

\section{A felelősségbiztosítások típusa}

A piacon elérhető klasszikus vállalati felelősségbiztosítások és szakmai felelősségbiztosítások tipológiáját a 2. táblázat tartalmazza.

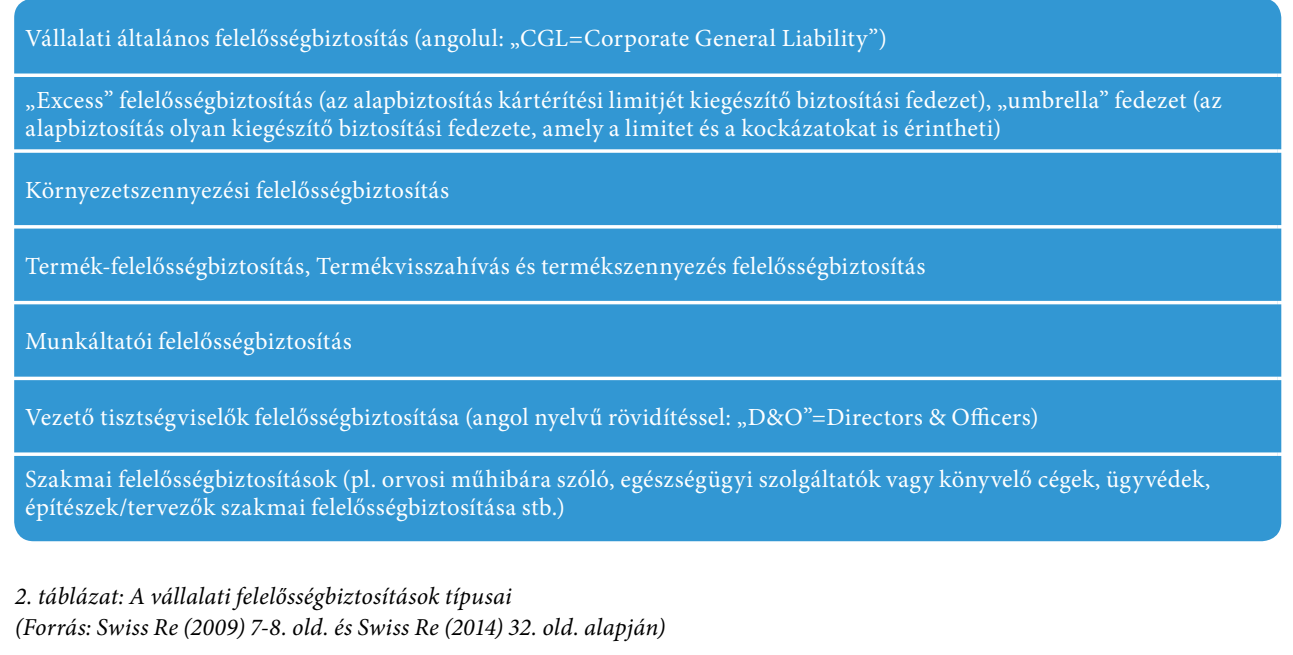

A társaságok a vállalati általános felelősségbiztosítást azon veszteségek fedezetére alkalmazzák, melyek a jogszerüen folytatott tevékenységük során velük szerződéses jogviszonyban nem álló, harmadik fél kárigényéből adódnak. Ez a felelősségbiztosítási szerződés fedezi a személyi sérüléses és dologi károkat. A biztositótársaság vállalja, hogy a kárt megtéríti a biztosított helyett, kivéve, ha az adott kár kizárásra került, vagy szándékosan okozták. Tekintettel arra, hogy a vállalati általános felelösségbiztosítás nem fedezi a a limiten felüli katasztrófakockázatokat, ezek fedezésében az ún. „excess” vagy „esernyö” (umbrella) felelősségbiztosítási fedezet segíthet, illetve nyújthat védelmet az üzleti vállalkozások számára. A környezetszennyezési felelősségbiztosítás kevésbé ismert biztosítási forma annak ellenére, hogy napjainkban egyre nagyobb fókuszt kapnak a környezetvédelemmel kapcsolatos kérdések. Magyarországon törvény írja elő a nagyobb mennyiségű hulladékot „termelő” és azt átvevő, szállító, tároló és kezelő vállalatok számára a környezetvédelmi biztosítás megkötését. Ezen kívül minden olyan esetben, amikor egy társaság a környezetét veszélyezteti, érdemes lehet ebben a konstrukcióban gondolkozni, hiszen egy káresemény esetén a helyreállítási költségek tetemes összeget jelenthetnek. A piacon ezen kívül léteznek ún. termék- vagy szolgáltatói felelősségbiztosítások is, amelyek a szerződéses jogviszonyban okozott, nem szakmai felelősségi károkra nyújtanak fedezetet. A munkaadók számára kiemelten fontos a munkáltatói felelősségbiztosítás, amely olyan esetben nyújt anyagi segítséget, ha a munkavállaló (vagy bárki, akinek a munkáltató a munkavégzés során személyi sérüléssel járó kárt okoz) munkahelyi balesetet szenved, s ennek kapcsán jogosan követel kártérítést a munkaadótól. A vezető tisztségviselők felelősségbiztosítása (D\&O - Directors \& Officers) a cégvezetőket védi a saját tevékenységükkel és saját döntéseikkel kapcsolatban felmerülő kártérítési igényekkel szemben. A szakmai felelősségbiztosítás sajátos szakmai kockázatokra nyújt felelősségbiztosítási fedezetet. Ez a biztosítási forma azokat a szakembereket védi (pl. ügyvédeket, alkuszokat, könyvelőket, orvosokat, gyógyszerészeket stb.), akik szakmai 
szolgáltatásaik nyújtása során harmadik személynek okoznak kárt. Ezek a harmadik személyek a szolgáltatás igénybevevői, akik jellemzően szerződéses jogviszonyban állnak a szakemberekkel (Rejda \& McNamara, 2014) ${ }^{13}$.

\section{A nemzetközi és a magyar felelősségbiztosítási piac elemzése}

A magyar felelösségbiztosítási piac globális összehasonlításban alulfejlett, a biztosítási penetráció jelentősen alacsonyabb a világátlagnál. Ahogy az a 3. táblázatból kitűnik, az Egyesült Államok felelősségbiztosítási piaca messze a legnagyobb a világon (a teljes világpiac díjbevételének több mint 52 százaléka (84 Mrd USD a teljes világpiac 160 Mrd-os díjbevételéből) az USA-ban realizálódik a 2013-as adatok alapján). Az USA-ban a 2013. évben a teljes GDP 0,5 százalékát költötték felelősségbiztosításra. Magyarországon ugyanez az arány csupán 0,06 százalék, ami - többek között - azt is mutathatja, hogy a magyar társaságok még nem ismerték fel a felelősségbiztosítás mint kockázatkezelési technika fontosságát. A jelentős különbség hátterében a két piac fejlettsége és jogrendszere közötti lényeges különbségek is azonosíthatók, ahogy azt is érdemes megemlíteni, hogy míg Magyarországot alulbiztosítottnak tekintjük, addig például Abraham (2008) az USA felelősségbiztosítási piaca kapcsán túlbiztosítottságról beszél.

\begin{tabular}{c|c|c|c|c|c|c|}
\hline \multirow{2}{*}{ Helyezés } & & \multicolumn{2}{|c|}{$\begin{array}{c}\text { Biztosítási dijak \& GDP } \\
\text { (milliárd USD) - 2013 }\end{array}$} & \multicolumn{2}{c|}{ Százalékos részesedés } \\
\hline & & $\begin{array}{c}\text { Felelósség- } \\
\text { biztosítás }\end{array}$ & $\begin{array}{c}\text { Teljes } \\
\text { nem-élet }\end{array}$ & GDP & $\begin{array}{c}\text { Felelősség- } \\
\text { biztosítás/ } \\
\text { Teljes nem-élet }\end{array}$ & $\begin{array}{c}\text { Felelös- } \\
\text { ségbiztosí- } \\
\text { tás/ GDP }\end{array}$ \\
\hline 1 & $\begin{array}{c}\text { Egyesuilt } \\
\text { Allamok }\end{array}$ & 84 & 531,2 & 16802 & $15,8 \%$ & $0,50 \%$ \\
\hline 2 & $\begin{array}{c}\text { Egyesuilt } \\
\text { Királyság }\end{array}$ & 9,9 & 99,2 & 2521 & $10,0 \%$ & $0,39 \%$ \\
\hline 3 & Németország & 7,8 & 90,4 & 3713 & $8,6 \%$ & $0,21 \%$ \\
\hline 4 & Franciaország & 6,8 & 83,1 & 2750 & $8,2 \%$ & $0,25 \%$ \\
\hline 5 & Japán & 6 & 81 & 4964 & $7,4 \%$ & $0,12 \%$ \\
\hline 6 & Kanada & 5,2 & 50,5 & 1823 & $10,3 \%$ & $0,29 \%$ \\
\hline 7 & Olaszország & 5 & 47,6 & 2073 & $10,5 \%$ & $0,24 \%$ \\
\hline 8 & Ausztrália & 4,8 & 32,7 & 1506 & $14,7 \%$ & $0,32 \%$ \\
\hline 9 & Kína & 3,5 & 105,5 & 9345 & $3,3 \%$ & $0,04 \%$ \\
\hline 10 & Spanyolország & 2,2 & 31 & 1361 & $7,1 \%$ & $0,16 \%$ \\
\hline & TOP 10 & 135 & 1150 & 46900 & $11,7 \%$ & $0,29 \%$ \\
\hline & Az egész világ & 160 & 1550 & 61700 & $10,3 \%$ & $0,26 \%$ \\
\hline & Magyarország & 0,067 & 1,3042 & 105 & $5,1 \%$ & $0,06 \%$ \\
\hline
\end{tabular}

3. táblázat: A felelösségbiztositási penetráció nemzetközi összehasonlitásban (Forrás: Swiss Re (2014), 5. oldal)
Mi a fő magyarázó tényező az eltérő felelősségbiztositási penetrációs értékek mögött? A US Chamber of Commerce által publikált 2013-as tanulmány ${ }^{14}$ egyértelmű, statisztikailag is szignifikáns kapcsolatot talált egy-egy ország jogrendszere, pontosabban a felelösségi károk (kártérítési joggyakorlat) szempontjából releváns jogi környezet és a felelősségi kártérítések, illetve a felelősségbiztosításra fordított összegek (a biztosítótársaságok oldaláról nézve a biztosítási díjbevételek) között. A tanulmány a jogrendszerek kártérítési jog szempontjából vizsgált költséges voltát két változóval írja le: az egy fơre jutó ügyvédek számával és a jogrendszer angolszász (common law, esetjog/szokásjog) vagy kontinentális (civil law) jellegével. Az eredmények alapján az angolszász országokban (USA, UK, Canada) a legmagasabbak a kártérítési költségek, és nem meglepő módon a felelősségbiztosításokra fordított összeg is ezekben az országokban a legmagasabb.

Egyik oldalról azt mondhatjuk, hogy a vállalatok racionálisan viselkednek, és amennyiben azt tapasztalják, hogy a felelősségi károkkal kapcsolatos kockázatok magasak, logikusan - saját érdekeiket követve - többet költenek ezeknek a kockázatoknak a fedezésére, vagyis felelősségbiztosításokra. A másik oldalról azonban - ahogy azt a fent jelzett tanulmány megállapítja - az USA jogrendszere komoly (a GDP 0,8\%-ára rúgó) pluszköltségeket okoz a vállalatoknak európai versenytársaikhoz képest, ezáltal csökkentve versenyképességüket a globális versenyben.

Baker (2011) azt állítja, és idősorokkal is szemlélteti, hogy hosszú távon szemlélve a kérdést, a felelősségbiztosítási díjbevétel lényegében a vagyonbiztosításokkal és a GDP-növekedéssel arányosan, azzal összhangban nőtt az 1939 és 2008 közötti időszakban az USA-ban, így lényegében és elsősorban a gazdaság növekedésének következményeként nőtt a felelősségbiztositási díjbevétel (ugyanakkor a felelősségbiztosítási dijbevétel jelentősen nagyobb volatilitást mutatott).

A két eltérő megközelítésből két dolgot mindenképpen leszűrhetünk (az USA adatsorait vizsgálva): a gazdasági növekedéssel hosszú távon együtt mozog az ezen javak működtetésével kockáztatott vagyon nagysága (és a vagyonbiztosítások volumene) és az ezekhez tapadó felelősségi kockázat is. A másik pedig az, hogy egy-egy ország jogrendszere és annak változása mindenképpen fontos tényező a felelősségbiztosítási piac fejlődésében. Láttuk, hogy a kiemelkedő amerikai penetráció a gazdaság méretével és a jogrendszer specifikumaival is kapcsolatban van. Mi a helyzet Európában? Tekintsük át a magyarországi helyzetet európai összehasonlításban!

Európai összehasonlításban a magyar piaci penetráció a középmezőny végén foglal helyet, 2012-ben 0,07 százalékos díjbevétel/GDP értékkel ${ }^{15}$. A magyar részarány az európai felelősségbiztosítási piacból mindössze 0,2 százalékos (70 millió EUR-s a magyar piac a 28653 millió EUR nagyságú európai piacon belül), ami kis mértékben alacsonyabb, mint a teljes nem-életbiztosítási piaci részesedés (ez 0,28\%-os értéket mutat 2012-ben ${ }^{16}$ ).

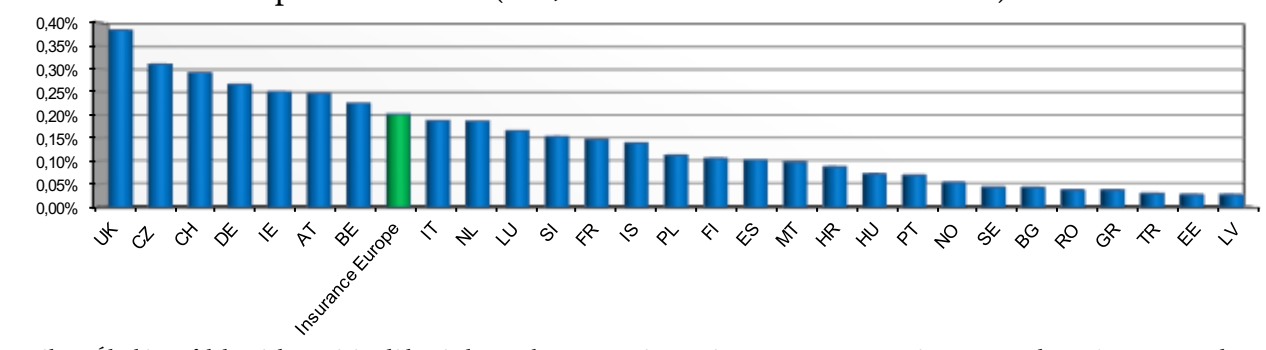

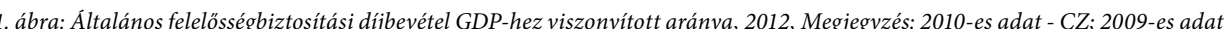
CY; 2008-as adat - SK (Forrás: Insurance Europe, 2012) 
Az európai biztosítási piac 2003 és 2012 között, 10 év leforgása alatt díjbevételben közel 15 százalékos növekedést mutatott. Ez kismértékű növekedést jelez (alacsonyabbat, mint a teljes nem-életbiztosítási piac), ugyanakkor itt figyelembe kell venni, hogy ez az időszak a válság éveit is magában foglalja, és ebben az időszakban 3 éven keresztül $(2008,2010$, 2011) ez a piaci szegmens is csökkent. Ha részletesebben is megnézzük az egyes országokat, akkor látszik (lásd 1. melléklet), hogy az összesített adatokra komoly hatást gyakorolt a legnagyobb piac, az Egyesült Királyság piacának jelentős csökkenése. Az Egyesült Királyságot figyelmen kívül hagyva a piac 27 százalékot növekedett a vizsgált 10 évben.

A magyar biztosítási piac nagyon alacsony szintröl indult egyenletes növekedésnek (lásd: 2. ábra). A 2014. évben a teljes felelősségbiztosítási piac ${ }^{17}$ bruttó díjbevétele kb. 20 milliárd Ft volt. A kárhányad átlagosan 23 százalék körül alakult az utóbbi 10 évben (2005-2014), olyan piaci szegmenst jelezve, amelynek átlagos profitabilitása magasabb, mint a teljes nem-életbiztosítási piac profitabilitása

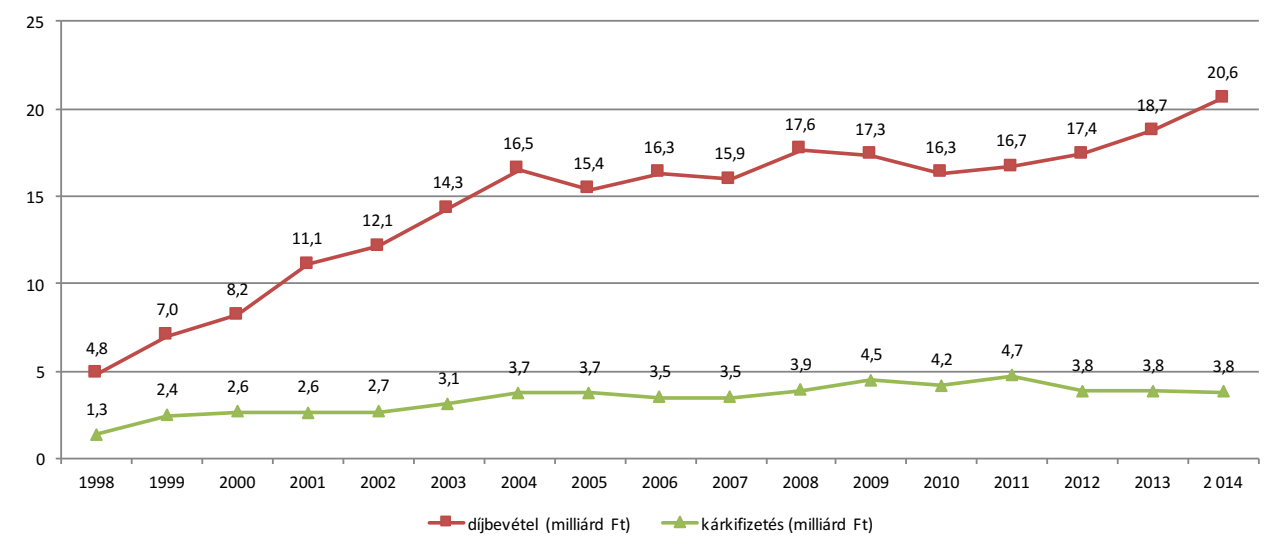

2. ábra: A magyar felelossségbiztositási piac alakulása (dijbevétel és kárkifizetés 1998-2014) (Forrás: MNB (2015))

Ezt alátámasztja a 3. ábrán szereplő kárkifizetési hányad alakulásának ágazonkénti elemzése, amely egyértelműen mutatja, hogy a nem-életbiztosítási ágazatok között a felelösségbiztosítások kárkifizetési hányada alakult a 2008-2014 közötti időszakban (minden egyes évben) a legkedvezőbben.

Ha a függőkártartalékok és a kárrendezési költségek alakulását is megvizsgáljuk, látható, hogy ezen a fejlődő piacon jelentős eltérés van a kárkifizetési arány és a kárhányad között. ${ }^{18}$ Amint az a 4. ábrán látható, a kárkifizetési hányad esetében tapasztalt eltérés jelentős mértékben csökken a bruttó kárhányad mutatónál, mert a függőkártartalékok és kárrendezési költségek aránya 10-15 százalékkal magasabb a nem-élet üzletág azonos mutatójának átlagánál. Mi állhat ennek az eltérésnek a hátterében? Hosszú távon a kárkifizetésnek és a kárráfordításnak - a kárrendezési költégektől eltekintve - egyformának kellene lenni, hiszen a tartalékok éppen azért szükségesek, mert azokat utóbb ki kell fizetni. A 4. ábra jelentheti azt, hogy a felelősségbiztosítási ágazat túl van tartalékolva, de jelentheti azt is, hogy a tartalékolást végző szakemberek előre gondolkodtak (számítva a jogérvényesítési harmonizációra, az ebből eredő nagyobb kárszámra, illetve magasabb kárigényekre), és a későbbiekben ez meg fog jelenni a kifizetések növekedésében is.

\section{Kárkifizetés/bruttó díj ágazatonként}

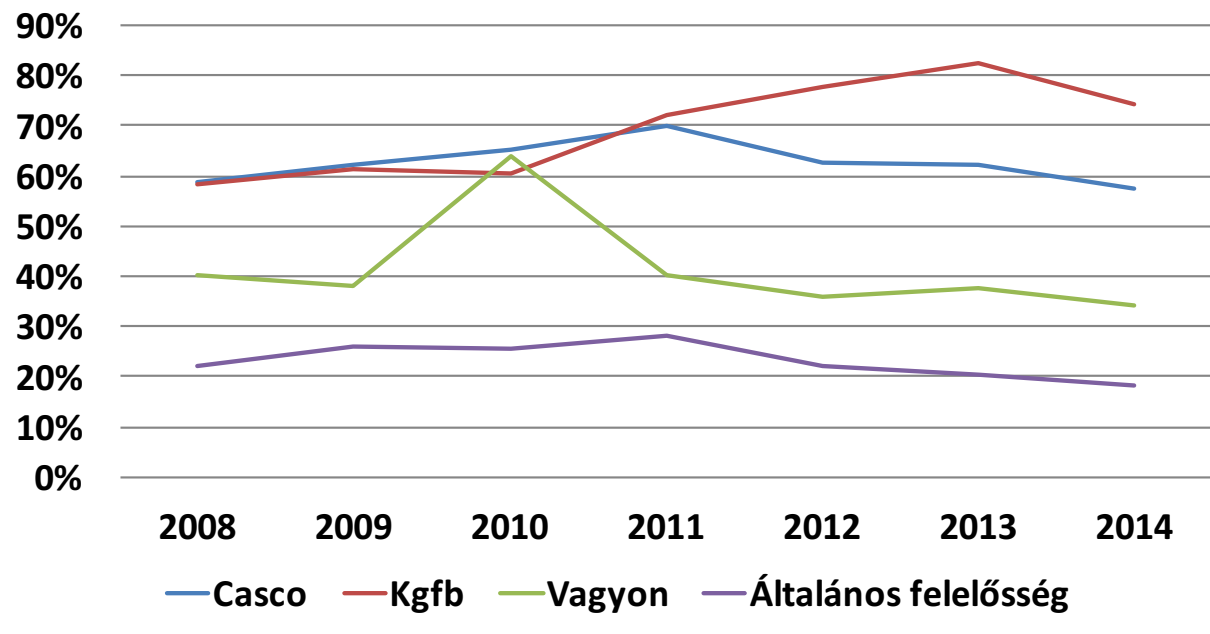

3. ábra: Kárkifizetési hányad (kárkifzetés/bruttó dij) alakulása ágazatonként (2008-2014) (Forrás: MNB (2015))

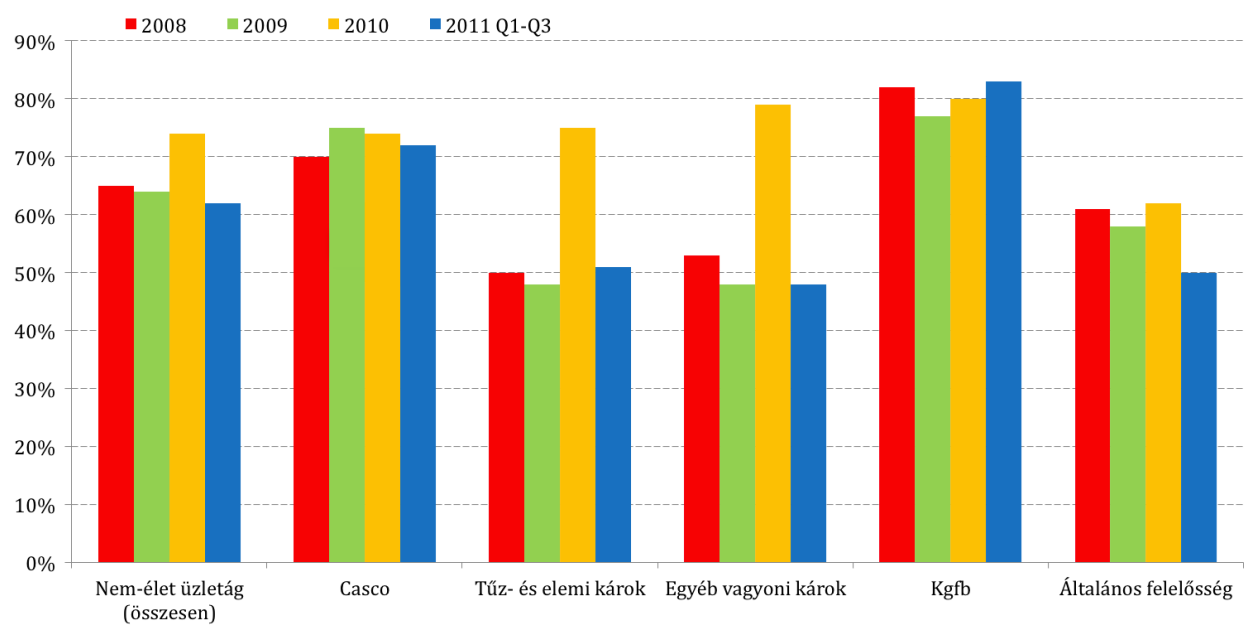

4. ábra: A nem-élet ági bruttó kárhányad alakulása ágazatonként (2008-2011) Megjegyzés: (a tárgyidószaki károkra történt bruttó kárkifizetés + a tárgyidőszabi karokn tárgyidószakra vonatkozó kárrendezési költségek) / tárgyidószaki bruttó dija (Fomís: PSZÁF (2011)) 
A magyar felelősségbiztosítási piac 2014-ben az előző évhez képest jelentős, a nemélet piac növekedését jelentősen felülmúló, 28,6 százalékos növekedést produkált: a felelősségbiztosítási díjbevétel a 2013-as 16,4 milliárdos szintről 21,1 milliárd Ft-ra nőtt. Az 5. ábra a teljes díjbevételt és a felelősségbiztosítás három fö típusának arányát mutatja a 2013. és 2014. évekre vonatkozóan. A teljes dijjbevétel növekedése részben magyarázható a szerződések növekvő számával (szakmai felelősség és $\mathrm{D} \& \mathrm{O}$ területeken), illetve részben a biztosítási átlagdíjak növekedésével (aminek hátterében részben összetétel-hatás, részben a szolgáltatási tartalom bővülése állhat ${ }^{19}$ ).

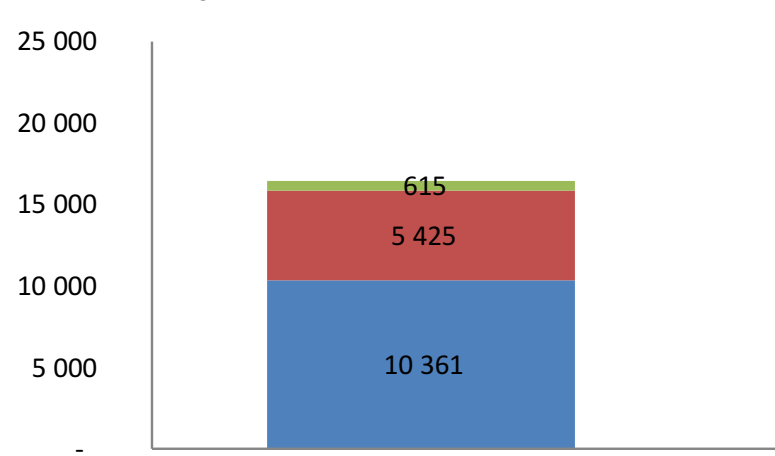

2013

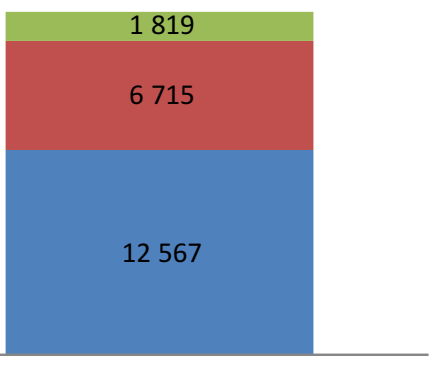

2014
- Általános felelősségbiztosítás —Szakmai felelősségbiztositás

- Vezetői felelősségbiztosítás - D\&O

5. ábra: A magyar felelóssségbiztositási piac állománydija (2013-2014) (Forrás: MABISZ (2015))

Az általános felelősségbiztosítási piac állománydíjban 22 százalékot, a szakmai felelősségbiztosítási piac 23,8 , a vezető tisztségviselők felelősségbiztosítási piaca pedig - alacsony bázisról - 195 százalékot nőtt. Mi állhat ez utóbbi, kimagasló növekedés hátterében? 2014-ben a vezető tisztségviselők felelősségbiztosításának szegmense (a felelösségbiztosítási piac mindössze 8,8\%-a) nagyobb figyelmet és hangsúlyt kapott, köszönhetően a magyar Polgári Törvénykönyv jelentős változásainak, amelynek értelmében 2014. március 15 -i hatállyal a társaság és a társaság vezető tisztségviselői egyetemlegesen felelnek

\section{A magyar felelösségbiztosítási piac 2014-ben \\ 28,6 százalékos növekedést produkált.}

a társaság által okozott károkért, amennyiben a szerződéses viszonyon kívül, saját maga eljárva okoz kárt. A jogi változás (illetve ennek gyakran ellentmondásos értelmezése) és a megnövekedett figyelem eredményeként a vezetői felelősségbiztosítási piac jelentősen nőtt: az állományra vonatkozó 2014. évi záróadat 1,819 milliárd Ft a 2013. évi 615 millió Ft-hoz képest. A szerződések száma továbbra is nagyon alacsony 2014-ben (csupán 3811).
A szerződések alacsony száma ellenére (a felelősségbiztosítási piac 3,7\%-a), a teljes felelősségbiztosítási piac szempontjából a D\&O biztosítások állománydíjának növekedése (1,204 milliárd) a tavalyi év 4 milliárdos növekedésének majdnem 30 százalékát tette ki.

A magyar piac belső struktúrájáról korlátozott információk állnak rendelkezésre. A szakirodalomban két fontos sajátosság jelenik meg. Az egyik a piac, illetve ezen belül egyes részpiacok mérete: egy-egy részpiac sok esetben olyan kicsi, hogy a méret önmagában lehetetlenné teszi az érdemi versenyt a piaci szereplők között úgy, hogy a veszélyközösség mérete még elegendően nagy legyen. A másik pedig a piaci koncentráció kérdésköre. Nagy-Micski (2012) szakmai felelősségbiztosításokra vonatkozó kutatása ${ }^{20}$ szerint a kép differenciált, vannak egészen koncentrált és mérsékelten koncentrált részpiacok is. Számításaik szerint a 17 szereplős általános felelősségbiztosítási piac koncentrációja a nem-életbiztosítási piachoz képest magas, a legnagyobb 3 szereplő piaci részesedése 60 , a legnagyobb öt szereplőé 75 százalék körüli. A Herfindahl-Hirschman Index (HHI) közel 2500, ami már erős koncentrációt mutat. Ezen belül a szakmai felelősségbiztosítások egyes szakmákra vonatkozó koncentráltsága még magasabb. A magas koncentráció okai között Nagy-Micski (2012) elemzése szerint a kereslet alacsony szintje mellett a kisméretű veszélyközösség, a károkkal kapcsolatos információk rendelkezésre állásával kapcsolatos problémák és a magas váltási költségek állnak. Egyes szakmákban a kereslet aggregálása is növeli a koncentrációt (pl. az ügyvédek saját biztosítási egyesülete (MÜBSE) kvázi egyszereplős piacot hoz létre).

\section{A gazdaság növekedésével a potenciális és}

várhatóan a tényleges károk nagysága nő.

\section{Felelősségbiztosítások jövője - a várható tendenciák}

A szakirodalom egységes abban, hogy a felelősségbiztosítások jelentősége Magyarországon (is) nőni fog a jövőben. Miért? Mi indokolhatja a felelősségbiztosítások szerepének pozitív változását?

Egyrészt a gazdaság növekedésével a potenciális és várhatóan a tényleges károk nagysága nő (a tapasztalatok alapján a GDP növekedésénél nagyobb mértékben). A Swiss Re (2015) adatai szerint a felelősségi károk nagysága hagyományosan (2004 előtt) nagyobb mértékben nőtt, mint a GDP (és az infláció), s ugyan ez a kapcsolat a tartalékolási ciklus megváltozásának és a recessziónak betudhatóan megváltozott 2004 után, azonban a válságot követően várható, hogy ismét helyreáll a „hagyományos kapcsolat”. Az egészségügyi költségek növekedése is prognosztizálható. Ezzel nő a gazdaság szereplőinek kitettsége is. Így a felelős gazdasági szereplők várható reakciója az, hogy a növekvő kockázatok kezelésére egyre nagyobb arányban és mértékben alkalmaznak felelősségbiztosítást. A gazdasági növekedés olyan pozitív hatást is gyakorolhat a piac alakulására, hogy több piaci szereplő engedheti meg magának a felelősségbiztosításra szükséges ráfordítást. 
Másrészt Magyarországon is arra számítunk, hogy az objektív (no fault) felelősségi alakzatok folyamatosan teret nyernek a társadalomban. A szakmai tevékenység során okozott károkért való felelősség alóli kimentés lehetősége csökken, $s$ a bírósági gyakorlat is egyre szigorúbb ebben a tekintetben. Ez is abba az irányba mutat, hogy a felelősségbiztosítási penetráció a jövőben növekedni fog.

A tudatosság szintjének várható fokozatos növekedése növelheti a károsultak kárigény-érvényesítési hajlandóságát. Ennek valószínűségét a szigorodó, a károsultak érdekeit szem előtt tartó bírósági gyakorlat is növelheti. Új fejleményként a kollektív kártérítési keresetek (collective redress ${ }^{21}$ ) gyakorisága is nő, aminek hatása nehezen becsülhetö. Amennyiben a komoly kártérítési kötelezettséggel záruló esetekkel kapcsolatos információk publicitást is kapnak, az szintén pozitív hatást gyakorolhat a felelősségbiztosítások keresletére és a kárigény-érvényesítési hajlandóságra egyaránt.

A felelősségbiztosításokkal lefedett károk köre is várhatóan nő. Első példaként álljon itt a kiberbiztosítások (cyber insurance) új és növekvő szegmense. 2006 és 2013 között az USA-ban ötszörös növekedést mutatott a kiberbiztosítási szegmens az 1 milliárd \$-ra becsült globális piacon, és a szakemberek mind a kereslet, mind a limitek további növekedését várják a jövőben. A legfontosabb hajtóerők között a kiberkockázatokkal kapcsolatos hírek és káresetek növekvő száma, a növekvő tudatosság és a harmadik fél által előírt fedezetek szerepelnek (Advisen, 2014). Hasonlóképpen említhető a vezetô nélküli járművekhez (pl. a Google önjáró autója) kapcsolódó termékfelelősség kérdésköre, vagy a palagáz-kitermelés kapcsán közismertté vált hydro-fracking technológia (a föld mélyében fellelhető földgáztartalékok kitermelésének új módszere) környezeti hatásainak kezelése, vagy éppen az orvostudomány fejlődése kapcsán előkerülő új mühibaperek. De ebbe a sorba illeszthetők a pénzügyi válság kapcsán középpontba került új vállalati kormányzási (corporate governance) követelmények ${ }^{22}$, és ennek kapcsán a vezetői felelősség szigorodása és kiterjesztése is. Friss magyar példát említve az új Ptk. által 2014-ben bevezetett sérelemdíj is új elemet jelent a felelősségbiztosítási szakemberek számára. Mindezen új, változó kockázatok új megoldásokat igényelhetnek.

\section{A hazai társaságok által kötött biztosítási szerződésekre \\ jellemző kártérítési limitek sok esetben alacsonyak.}

Ezen kívül egyre több szakma számára írják elő a jogszabályok (vagy a szerződéses partnerek) kötelező szakmai felelősségbiztosítás kötését, ami a piac figyelmét a felelősségbiztosítások irányába tereli. A jogszabályi kötelezés mellett egyre több megrendelő írja elő a beszállítók számára a felelősségbiztosítást (vagy azzal egyenértékű biztosítékot)

A hazai társaságok által kötött biztosítási szerződésekre jellemző kártérítési limitek sok esetben alacsonyak. Ez részben egyes felelősségbiztosítások kötelező természetéből fakad, ugyanis a társaságok/intézmények gyakran nincsenek tisztában a biztosítás valódi jelentőségével, az okozható kár mértékével, és/vagy nem állnak rendelkezésre a szükséges és elégséges fedezet eléréséhez nélkülözhetetlen pénzügyi források, ezért elsődleges céljuk, hogy a lehető legalacsonyabb díjon kössék meg a szerződést. Mivel a törvényalkotó a megfelelő fedezet kérdését lényegében nem szabályozza, a kérdés a biztosítottak (és persze a biztosítók, biztosításközvetítők) szakértelmén és hozzáállásán múlik elsősorban. A legtöbb társaság/intézmény vezetése ugyanakkor nem rendelkezik azzal a szakértelemmel, hogy pontosan felmérje a társaságot fenyegető kockázatokat és azok nagyságát, ami szintén ahhoz vezethez, hogy a választott felelősségbiztosítás nem fedezi a lehetséges kockázatokat. Ahogy a társaságok és vezetőik egyre több tapasztalatot szereznek a limitek megfelelőségéről (meg nem felelőségérôl), az alulbiztosítottság csökkenése (a limitek növekedése) is logikus lenne a jövőben, ami szintén a biztosítottság javulását és a biztosítási piac növekedését vetíti előre.

\section{Következtetések}

Bár az elmúlt években a jogszabályi háttér változásai hozzájárultak a felelősségbiztosítás szerepének növekedéséhez, a hazai vállalkozások továbbra sincsenek teljesen tisztában annak jelentőségével. A tudatosság szintje vélhetően lassan változik a jövőben, hiszen a joggyakorlat szigorodásának negatív gazdasági hatását késleltetve, jelentős késéssel érzékelik majd a vállalatok, és csak ezt követően számíthatunk a vállalati gyakorlat jelentős változására, ezzel az általános felelősségbiztosítási penetáció növekedésére.

Csupán a biztosítási szerződés megléte önmagában nem elégséges, ha az nem fedezi a valódi kockázatokat, vagy nem a megfelelő fedezetet biztosítja egy adott kockázatra. A kötelező szakmai felelősségbiztosításokra vonatkozó elöírások finomítása, illetve a közvetítőrendszer szakmai sztenderdjeinek fejlődése segítheti, hogy valódi fedezeteket tartalmazzanak a felelősségbiztosítások. Ez nem csupán a társaságok kockázatcsökkentése miatt lenne fontos, hanem azért, mert ezáltal biztosítható, hogy a károsultak megfelelő kártérítést/kompenzációt kaphassanak.

A biztosítási szektor is sokat tehet a piac fejlödése érdekében. A pénzügyi-biztosítási tudatosság és ismeretek szintjének növelésében a szektor kommunikációs tevékenységének és a közvetítőrendszer tanácsadási szerepének fontos feladata van. Az új igényekre termékinnovációkkal és a meglévő termékek finomításával, átláthatóságának növelésével reagálhatnak a biztosítók - mindkettő pozitív hatást gyakorolhat a keresletre. A biztosítási kultúra fejlesztése, a szabályozó környezet társadalmi jólétet növelő változása, finomítása érdekében kívánatos a szektor legfontosabb érintettjeinek (biztosítók, közvetítők, szabályozók) együttműködése.

${ }^{*}$ Pandurics Anett - Corvinus Egyetem, Posta Biztositó (pandurics.anett@mpb.hu)

Markó Olga - Szent István Egyetem (marko.olga@gtk.szie.hu) 
Key words: Liability Insurance, Directors and Officers Liability Insurance, Economic Stability, Tort Law, Risk Management, Market structure

JEL: D4, G22, G32, K13

\section{SUMMARY}

Although risk is an inevitable part of our lives, risk can be managed with several intentional techniques. One of the possible ways of preparing for unexpected events and decreasing future risks is insurance. Without proper risk management techniques, rarely occurring large damages could destroy the company affected, could leave the injured without proper compensation and could have a negative effect on the overall economy (through increased volatility and the burden of recovery). Insurances and liability insurances therefore have an outstanding stabiliser role through spreading risks. The most important feature of liability insurances is that three-pole, complex relationship, that develops as a result of the matter of fact, that the liability insurance company covers claimes caused by the insured to third parties. The aim of the article is to shed light on the special features, on the role and significance of liability insurances, and to describe the present situation of the Hungarian liability insurance market and the potential tendencies in the future, focusing on the corporate liability market.

\section{HIVATKOZÁSOK}

'A mai magyar vállalati vagyonbiztositási szerződések túlnyomó része ún. all risk típusú, így ennek az eltérésnek a jelentősége csökken. ¿ $\mathrm{z}$ csak a a a a ese magyar gyakorlatban jellemző, hogy a jogi képviseleti költségek a limiten belül értendők.

'Egy ismert, rendkívüli esemény a 2001. szeptember 9-ei terroristatámadás, amely az USA történetének második legnagyobb (a legnagyobb a Katrina hurrikán volt) kárkifizetését (32,5 milliárd \$2001-es árakon) vonta maga után. A kifizetések számos ágazatból történtek, a leginkább érintettek a vagyonbiztositások és a különbözỏ felelösségbiztositások (pl. aviation insurance) voltak. Ezek a kifizetesek jelentơs szerepet jatszottak az ujjaépites finanszirozasában, kezzzel foghatová téve a biztositások stabilizalo szerepet a tragedia kapcsan. Ez az esemény pelda arra is, hogy teljesen varatlan, korabban nem létezett események is okozhatnak olyan felelösségi károkat, amelyeket a szerzödéskötések pillanatában senki nem láthatott elöre. Nem véletlen az sem, hogy a dijak is sok

" A függőkár-tartalékok két alapesete: 1) a tételes függökár-tartalék (RBNS=reported but not settled) a már bejelentett (és még nem rendezett) károkra képzett tartalék, és 2) a bekövetkezett, de még be nem jelentett (IBNR=incurred but not reported) károkra képzett tartaléko

Tafae, Peter.

2013,317, Nagy-Micski (2012) 90.

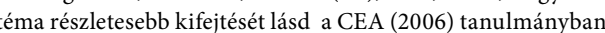

${ }^{12}$ Egyrész t a biztositó szakértelmével és tapasztalatával segitséget nyúithat az érintett társaságnak az alaptalanul támasztott kárioények elhárításában. Másrészt a biztositó segithet abban, hogy a megalapozott igénnyel fellépő károsult minél elöbb kártéritéshez jusson abban az esetben, ha a károkozó maga esetleg nem együttmüködő (vagy adott esetben már megszűnt).

"Jusson abban az esetben, ha a karokozó maga esetleg nem egyuttmúkodo (vagy adott esetben mín

${ }^{14}$ US Chamber Institute for Legal Reform (2013)

${ }^{15} \mathrm{Ez}$ az érték 2003-2012 között átlagosan is 0,07\%-os volt, alacsony szórással: 0,06\% és 0,08\% közötti értékekkel.

Insurance Europe (2014), 46.o.: 2012-ben a magyar piac mérete 1.276 millió EUR, a 32 ország adatait tartalmazó európai piac mérete pedig 450.669 millió EUR volt ugyanebben az évben.

${ }^{17} \mathrm{Az}$ adatok a kötelező gépjármú-felelossegbiztositási piac adatait nem tartalmazzák.

kapcsolatban ale kezésre ilyen adat.

dédések átlagdija jellemzően magasabb.

20A hivatkozott kutatás a publikusan elérhető statisztikákat és információkat (pl. a társaságok termékkínálatának feldolgozását)
'2013. június 11-én, az Európai Bizottság által kiadott 2013/396/EU számú az uniós jog által biztositott jogok megsértése tekintelében a jogsértés megszüntetééére és kártérítésre irányuló tagállami kollektív jogorvoslati mechanizmusok közös elveirő̉l szóló ajánlása is felhivja a figyelmet erre a kérdéskörre. A magyar jogrendszerben is léteznek hasonló jogintézmények: közérdekú kereset, pertársaság.

Középpontba kerültek az auditcégek és folyamatok. Sok szó esettlesik a vezetók megfelelö ösztönzőket tiztositój juvadalmazásáról is.

\section{IRODALOMJEGYZÉK}

1. Abraham, Kenneth S. (2008): The Liability Cen University Press, Cambridge, MA

2. Advisen (2014): Cyber Liability Insurance Market Trends: Survey, White Paper, October; http://www.advisenltd.com/2014/10/28/ cyber-liability-insurance-market-trends-survey/, 2015-08-10

3. Baker, Tom (2011): The Shifting Terrain of Risk and Uncertainty on the Liability Insurance Field, DePaul Law Review, Vol. 60, P. 521, U of Penn, Inst for Law \& Econ Research Paper No. 10-32.

http://dx.doi.org/10.2139/ssrn.1721745

4aker, Tom-Siegelman, Peter (2013): The Law and Economics of Liability Insurance: A Theoretical and Empirical Review, anuary, http://works.bepress.com/peter_siegelman/15; 2015-07-20.

5. CEA (2006): The Contribution of the Insurance Sector to Economic Growth and Employment in the EU, June; http://www.insuranceeurope.eu/uploads/Modules/Publications/Web\%20Contribution\%20of\%20the $\% 20$ Insurance $\% 20$ 6.

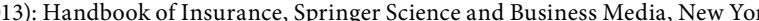

(t) $/ /$ dx. (e.

Inswrang, Robert P.- Wilkinson, Claire (2014:

Terrorism Risk - a Constant Threat, Impacts for Property/Casualty Insurers,

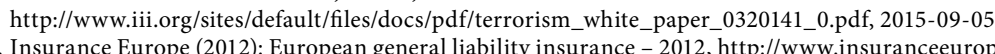

8. Insurance Europe (2012): European general liability insurance - 2012, http://www.insuranceeurope.eu/uploads/Modules/

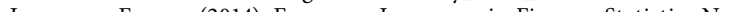

(E) uploads/Modules/Publications/european-insurance-in-figures-2 pdf, 2015-08-14

10.MABISZ (2015): Vagyonbiztositás, 2014. évi adatszolgáltatás, Budapest

1.Marko Olga-Pandurics Anett (2015): Role of the liability insurance in the enterprise risk management, 5th International Conference on Managentent, 2015. június 18-20., előadás, Gödölló

2.MNB (2015): Az MNB által felügyelt szektorok adatainak idősorai - Biztositási szektor; http.//felugyelet.mnb hu/data/

Moore, W. F. (1905): Liab
surance (Sept.), pp. 319-339. kultúra Közzpont támogatísíval A szakmai felelössè

15andurics Anett (2015): Felelolosségbiziztosittások szerepe, jelene és jövőjje, Felelösen a jövőért, Napi Gazdaság Konferencia, elöadás, május 21.
16. PSZAFF (2011): Ko

zati jelentés - 2011. december,

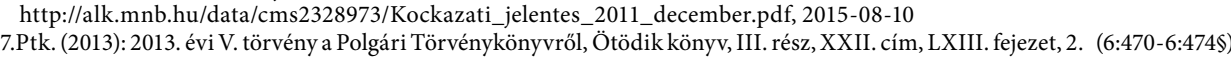
18.Rejda G. E., McNamara M. J. (2014): Principles of Risk Management and Insurance, 12. kiadás, Pearson 582-592 old.

9.Swiss Re (2009): Commercial liability: a challenge for businesses and their insurers, Sigma, 2009/5

20.Swiss Re (2014): Liability claim trends: emerging risks and rebounding economic drivers, Sigma, 2014/4 22.Taffae, Peter R. (2009): The ABCs of D\&O Insurance Clauses, Dec, 21 .,

www.propertycasualty360.com/2009/12/21/the-abcs-of-do-insurance-clauses, 2015-07-21

.Trieschmann J. S., Hoyt R., Sommer D. (2005). Risk Managenent and Insurance, 12. kiadás, Thomson-South Western 24.US. Chamber Institute for Legal Reform (2013): International Comparisons of Litigation Cost - Canada, Europe, Japan

pp.115-136.
http://dx.doi.org/10.1257/jep.5.3.115 